\title{
Applicants'or Students' Perception of Kazakhstani Universities Admission Tests and Exams
}

\author{
Zhazira Turlanbekova \\ Graduate School, Kazakh National Pedagogical University after Abai, Kazakhstan
}

Copyright $(\subset 2015$ by authors, all rights reserved. Authors agree that this article remains permanently open access under the terms of the Creative Commons Attribution License 4.0 International License

\begin{abstract}
This study is designed to describe applicants'/students' perception of admission tests and exams at Kazakhstani institutions. Often Kazakhstani higher education specialists make amendments in the curriculum, educational policy, and teaching methodology without considering the students' voice. According to the researcher's observation, Kazakhstani government did a little research on students' perception of admission tests and exams at Kazakhstani universities. Since all Kazakhstani universities admit applicants according to the Unified National Testing (UNT)/Complex Testing of applicants (CTA), the researcher focused on the UNT/CTA. The goal of the research paper is to observe students' perception about the UNT and international tests.
\end{abstract}

Keywords Kazakhstan, Students, Admission Tests and Exams, Students' Psychology and Stress

\section{Introduction}

Kazakhstan has 136 universities, among them 9-National Universities, 33-State Universities, 16-JSC Universities, 13-Non-Civil Universities, 63-Private Universities and two International Universities: Nazarbayev University and International University after Yassaui [1]. Except Nazarbayev University, all Kazakhstani Universities have the same admission criteria. Kazakhstani universities require the Unified National Testing results (UNT). In 2004, the first UNT was integrated in Kazakhstan. The goal of the UNT is to examine high school students' knowledge and define who will be admitted to Kazakhstani universities [2]. Students with high UNT scores can apply for the State Scholarship [3]. Universities of Art, Cinema, Architecture and some other universities, in addition to the UNT, require applicants to have a specific art exam. The Complex Testing of applicants (CTA) is an alternate test to the Unified National Test (UNT) for those who graduated from a high school some time ago, or graduated from vocational schools.
Kazakhstan has many universities that teach in the English language. If the teaching language is English, Universities require an applicant to have an English language proficiency test (IELTS, TOEFL etc.) or to take a university English language entrance test. Nazarbayev University does not require the UNT/CTA results. It has its own exams, such as Subject Entrance Test and an English language test. For Direct Admission, Nazarbayev University accepts IELTS, TOEFL, SAT and ACT results [4]. International School of Economics (ISE), at Kazakh British Technical University (KBTU), is a joint program of the School of London and KBTU. Therefore, ISE, in addition to the UNT/CTA test, requires applicants to take Advanced Placement test [5].The UNT became the main discussion topic for 11th grade high school students, parents and teachers. Kazakhstani psychologists claim that the UNT has a negative effect on high school students' psychology [6]. There are many opinions about the UNT. The purpose of this study is to find out students' perception about universities' admission tests and exams.

\section{The Review of the Literature}

\section{Unified National Testing}

The Unified National Testing combines final exams of high school and entrance exams of higher education. Thus, high school students take the UNT to receive high school diplomas and to be admitted to Kazakhstani universities[7]. High school students who studied 11 years for excellent grades can get "Altyn Belgi"(translation: Altyn Belgi Golden Sign) status. Students with "Altyn Belgi" status are eligible to the State grant (scholarship). But they must prove "Altyn Belgi" status with high UNT results [8].

The UNT consists of five subjects: 1) Mathematics, 2) History of Kazakhstan, 3) Kazakh language for those who study in Kazakh schools or Russian language for those who study in Russian schools, 4)Russian language for those who study in Kazakh schools or Kazakh language for those who study in Russian schools, 5) and the subject of choice 
(student/applicant chooses one subject).Each subject has 25 questions. Each correct answer is assessed with one score. Passing score is 50. If applicant does not receive 50, he/she will not be allowed to study in university. The UNT result is applicable only one year. The UNT takes 3.5 hours (210 minutes). Applicants take the UNT only once a year [9].The Complex Testing of applicants(CTA) is an alternate test to the Unified National Test (UNT) for those who graduated from a high school some time ago, or graduated from vocational schools. It is administered by the National Testing Centre under the Ministry of Education and Science of Kazakhstan [10].

Information revealing the content of the tests and codes of correct answers are considered as the State secrets. Therefore, testing centers (where UNT and CTA will take place) will be under a strict control of national security [11].

The UNT/CTA was started from 2004. During its history, the UNT generated lots of scandals and complaints. Applicants complained about weird and incorrect questions [12]. In 2013, Zhambyl oblast in Maikum region, the UNT center had a technical problem and a computer did not count applicants scores correctly. As a result, 30 applicants failed the UNT, and among them were academically outstanding students. Ayaulim Mukash, the best student, fainted and was hospitalized when she learned that she received only 35 points out of 125 [13]. In 2015, five high school students committed suicide because they could not get expected results from the UNT [14].

High school ranking is assessed in accordance with students' UNT results. Therefore, school teachers and administration is highly interested in students' academic success and high UNT scores. School administration and teachers force students to get high scores from the UNT [15].

High school's ranking depends on the UNT results. Therefore, high school administration makes students to get ready for the UNT from the beginning of the year. During for one year, high school students study the UNT subjects and take practical tests. High school administration and teachers persuade high school students who have not good academic performance not to take the UNT. Thus, only high school students with good academic skills will take the UNT. In a result, every year, the number of students who wants to take the UNT is decreasing. In 2015 , only $70 \%$ of high school students decided to take the UNT. In Russian schools, 43\% of high school students refused to take the UNT[16].

\section{Research on the UNT}

National Testing Center conducted a research: "Students' Perception on the UNT". According to research results, there is not one equal answer about the UNT. The UNT has advantages and disadvantages. Disadvantages: corruption, possibility of cheating, illogic questions. Ranking of schools in accordance with the UNT results, was considered as disadvantage. Advantages of the UNT: it is an easy method to assess knowledge of big population and distribute scholarships. In addition the UNT is a transparent test. Students from different social background have opportunity to win the State grant[17].

\section{Future of the UNT}

Vice-Minister of Education and Science Murat Abenov said that the structure of the UNT will be changed. In the future, the UNT will be divided into two tests. First test will be for high school students who are finishing school. The purpose of school test is to assess high school student's knowledge. After finishing high school exam, those who want to continue education, will have a university entrance subject tests[18]. A. Sarinzhipov Minister of Education and Science said that the UNT will be taken a couple of times during one year. In addition, the UNT will have different type of questions, written assignments and essay [19].

\section{Research Methodology}

It is a qualitative research. Research tools were survey and interview. Since the UNT and the CTA are similar tests, researcher combined them as the UNT/CTA. Researcher had two groups of participants. Group one, participants who took the UNT. Group two, participants who did not take the UNT/CTA but they will take it after finishing high school or vocational school.

Group one consisted of 44 students who took the UNT. They were students of research universities of Astana and Almaty cities. Respondents were from two public, one JSC, one private and one international university. Thirty two respondents took IELTS, six took AP, three took TOEFL and nine took SAT tests. They finished high schools in Aktobe, Pavlodar, Astana, Taraz, Semei, Almaty, Atyrau, Chimkent, Kyzylorda and Petropalsk.

Group two: 44 high school students who did not take the UNT but will take it after finishing high school/vocational school. Eleventh grade high school students were from three public Kazakh secondary schools and one Russia public school. Participants from group two were from Almaty city.

Participants were chosen randomly. All in all, 88 students took part in the research project. Among participants were 53 females and 35 males. 80 participants completed the questionnaires and eight participants gave the interview.

The researcher engaged participants in three ways: a) the researcher went into the streets of the cities of Astana and Almaty and nicely asked passing students to complete the questionnaires and give an interview, b) the researcher asked acquaintances (who were studying in university or high school) to fill out the questionnaires, c) the researcher visited two high schools and two universities and invited students to complete the surveys and give interviews.

The researcher conducted two focus groups: Each focus group consisted of four students, two males and two females. The first focus group was with students who took the UNT. The second focus group was with students who did not have the UNT/CTA but will have it after finishing high /vocational school. Respondents from group two: two participants were vocational school students and two of them 
were $11^{\text {th }}$ grade high school students. Each focus group lasted from 30 minutes to 60 minutes.

Survey:

The researcher conducted two types of surveys: one survey was for students who took the UNT and second survey was for high school students who never had the UNT, but will have it after finishing high school/vocational school. Both surveys had the same questions with one purpose to find out students' perception about university entrance tests and the level of stress. Survey for group one (for students who took the UNT) consisted of eighteen closed questions and seven open questions. Second group of participants did not have the UNT and international exams. Therefore, the researcher asked vocational school students/high school students' opinion only about the UNT/CTA. Thus, the survey for students who will take the UNT, had eight closed questions and seven open questions.

\section{Results of the Study}

\section{Perception of students who took the UNT/CTA}

a) Focus group: The researcher had a focus group with four students. Two of them were males and two females. Three of them had the State scholarships. Four students had IELTS, one of them had SAT and one of them had AP certificates. Focus group was conducted in Russian and Kazakh languages.

Participants explained their opinions about the UNT/CTA. One of respondents said that the UNT is a good method to distribute scholarships. During three and a half hours it is possible to evaluate high school students' knowledge and award the scholarships. The UNT is a well-structured and effective method, but it needs to be improved. Especially, it is essential to develop the section concerning History of Kazakhstan. Often History of Kazakhstan has questions about detailed facts. These detailed questions might come from small passages of history that are not generally considered important.

The second student said that the UNT is a very narrow-minded test that does not allow student to reveal real knowledge, critical thinking and creativity. Knowledge of historical facts is not an assessment that says something about the student's real knowledge. Subjects such as History, Literature, Geography are mainly memorization. The UNT does not show a student's communication and writing skills, or critical thinking abilities. In other words, the UNT does not reveal a student's skills and talent.

The third student said that the UNT has advantages and disadvantages. The UNT is good assessment for a big number of population. It consists of five subjects, and an applicant must be psychologically strong to switch from one subject to another subject. The disadvantage is that the UNT is like a lottery ticket. Some students with bad academic performance might get high scores, but some other outstanding students might receive bad scores in spite of their knowledge and hard work. The respondent continued that some of her acquaintances who had bad academic performance in high school received high scores on the UNT because they were able to cheat and guess correct answers. As a result, they were admitted to university and got the State scholarship. But, they could not study at university and lost the State scholarship. On the other hand, students who studied hard for 11 years in high school, could not answer correctly to the UNT detailed questions about facts and received low scores.

The fourth student disagreed with the opinion that the UNT is memorization. Respondent said that subjects such as History, Geography, Literature and Biology subjects require good memory. But other subjects such as Physics, Mathematics and Chemistry make students to study hard and understand the content of subject. The student must know how to solve assignments. It is impossible to memorize all answers. The UNT is not only memorization, but it is also review of school knowledge. In addition, the UNT makes students study hard. Thus, the UNT assists student in acquiring new knowledge and using it in the future. Even useless Historical facts can be used in the future. He continued that the UNT cannot be a reason of suicide. Mass media exaggerates the situation about the UNT in order to make TV news interesting.

But two respondents said that the UNT might be an impulse for suicide for psychologically weak students. Then they told a story about one of the brightest students from their school who could not get enough UNT scores to prove "Altyn Belgi" status. As a result, she was ready to commit suicide. Suicide is an only way to survive for psychologically weak students. Especially, students who must prove their "Altyn Belgi" status have lots of psychological pressure from school administration, teachers and parents. These students must prove their "Altyn Belgi" status and receive high scores from the UNT. Eleven years they studied hard and had only excellent grades. But during three and a half hours, because of weird questions about History or Geography subjects, they might receive lower scores and cannot prove "Altyn Belgi" status.

One of the participants said that he is Kazakh but does not know Kazakh language. He said that he understands Kazakh language little, but cannot write, read or speak. But he got the highest score on the Kazakh language section, even higher than his friends who are fluent in Kazakh language. The UNT does not assess knowledge properly, it is like a lottery ticket, to win or to lose. UNT is not fair test, concluded participants.

Students tolerate a lot of pressure from school administration. The UNT results shows school's ranking. Therefore, school teachers and administration are highly interested in making their students to study hard, sometimes, they misuse their authority. One of participants said that her health worsened that she got physically and psychologically exhausted. As a result, after the UNT, she got sick and had treatment for some time. 
Participants suggested gradually eliminating the UNT, or changing the format of the test. They suggested adding a few open questions, or one written assignment, if it is possible, to include an oral assignment as well. Thus, the UNT will have some similarity with international tests such as SAT, AP, ACT, SAT, TOEFL and IELTS. These international tests have sections where student writes, solves, does assignments that make him/her think. Thus, these types of tests will assess real knowledge and critical thinking of a student.

One respondent supported the future UNT format. He said that it is a good idea to divide the UNT into two parts as a school exam and university entrance exam. He continued that if a student studied during 11 years, definitely he will get enough scores to pass the school test. At the same time, if a student studied hard during 11 years, for him/her will be easy to take the second university entrance exam after a short time. In other words, it is normal for a student to take two exams in a short period of time. In addition, the future two exams will select only the strongest students to study in university. But other participants disagreed and said the future UNT, two exams will make students have double stress.

Four participants supported the idea that it will be good if the UNT acquires some assessment techniques from international tests such as TOEFL, IELTS, SAT and ACT. They said that during international tests they did not have psychological pressure because they knew, if they fail an international test, they can retake it. Unfortunately, the UNT is given only once a year, therefore, many students perceive the UNT as a key of success to life. But, international tests are possible to retake during one year. In addition, international tests have breaks between sections. International tests assess student's real knowledge, critical thinking, communication and writing skills. One participant claimed that it is impossible to have an international test format in Kazakhstan due to Kazakh culture and different methods of teaching. But changing the format of questions will improve the UNT.

\section{b) Survey results of students who took the UNT/CTA}

Survey for students who had the UNT /CTA had 18 questions closed questions with answers "Yes", "No", "No Response". The researcher asked questions about the students' UNT/CTA perception, experience, stress level and opinion about international tests. Also, the survey had seven open questions.

Open questions of the survey:

1. What do you think about the UNT/CTA?

2. If you received a low score, what will you do?

3. What was the most scaring for you during UNT?

4. What do you suggest to improve the structure of the UNT/CTA?

5. What do you think about the future UNT which will be divided into two parts such as School Exam and University Entrance Exam and what you recommend?

6. What is advantage and disadvantage of international test?

7. What would you do if you fail international test?

\begin{tabular}{|c|c|c|c|c|}
\hline$№$ & Question & Yes & No & No answer \\
\hline 1. & Do you agree that UNT/CTA is an effective entrance test to university? & $25 \%$ & $68 \%$ & $8 \%$ \\
\hline 2. & Do you agree that UNT/CTA evaluates your knowledge properly? & $10 \%$ & $75 \%$ & $15 \%$ \\
\hline 3. & $\begin{array}{c}\text { Do you believe that studying for UNT/CTA assists in increasing your school } \\
\text { knowledge? }\end{array}$ & $53 \%$ & $45 \%$ & $3 \%$ \\
\hline 4. & $\begin{array}{c}\text { Do you believe that UNT/CTA is only memorization of knowledge that might } \\
\text { be forgotten after a short time? }\end{array}$ & $65 \%$ & $5 \%$ & $30 \%$ \\
\hline 5. & Do you believe that UNT/CTA defines your destiny? & $63 \%$ & $33 \%$ & $5 \%$ \\
\hline 6. & Do you think that UNT/CTA is a stressful test? & $65 \%$ & $23 \%$ & $13 \%$ \\
\hline 7. & Did your health worsen during preparation for the UNT/CTA? & $20 \%$ & $63 \%$ & $18 \%$ \\
\hline 8. & Did your health worsen after the UNT/CTA test? & $13 \%$ & $55 \%$ & $33 \%$ \\
\hline 9. & Were you worried during UNT/CTA? & $65 \%$ & $35 \%$ & $0 \%$ \\
\hline 10. & Did you sleep well before the UNT? & $40 \%$ & $48 \%$ & $13 \%$ \\
\hline 11. & Did you have worries or fears during UNT preparation? & $63 \%$ & $35 \%$ & $3 \%$ \\
\hline 12. & Did your hands/legs shake during the UNT exam? & $25 \%$ & $73 \%$ & $3 \%$ \\
\hline 13. & Did you have an increased heart rate during the UNT? & $45 \%$ & $55 \%$ & $0 \%$ \\
\hline 14. & During UNT, did you have a feeling that you forgot everything and could not \\
think or write? & $28 \%$ & $68 \%$ & $5 \%$ \\
\hline 15. & Did you have thoughts of suicide if you did not pass the UNT? & $8 \%$ & $88 \%$ & $5 \%$ \\
\hline 16. & Was international test stressful? & $35 \%$ & $50 \%$ & $15 \%$ \\
\hline 17. & Did you get worried during international test? & $25 \%$ & $63 \%$ & $13 \%$ \\
\hline 18. & Do you think that international tests evaluate your knowledge properly to get \\
\hline
\end{tabular}


No.1. Respondents replied that the UNT is mainly memorization; the UNT is not the best method to evaluate knowledge; the UNT is a lottery ticket; the UNT is a good method to distribute scholarships; the UNT has many illogic questions; the UNT has too detailed useless questions from small articles of text books; $6 \%$ of respondents did not reply to the question.

No.2. All respondents replied to the question No.2, that, if they receive low scores from the UNT or fail it, they will find job, go to military service, go to private school, or start to study for the future CTA.

No.3. $75 \%$ of respondents answered to the question No.3. that they were afraid to receive low scores or fail the UNT. Some students answered that they were scared from History section due to many weird questions. Few students responded that they were angry that the UNT defines their destiny, if they fail the UNT, their parents will have feeling of shame.

No.4. $87 \%$ of respondents replied to the question No.4. Students had different suggestions to improve UNT. Some students wanted to eliminate the entire UNT; some suggested to remove History section; some suggested to change History subject questions; few respondents said to add various questions to the UNT; to have open questions; to have written assignments; to have an oral exam; to have questions such as in international exams such as SAT or AP; to change the ideology and concept of the UNT because many students believe that the UNT defines destiny and future success depends only on the UNT results, therefore it is essential to make students understand that the UNT is not the end of the world; to have opportunity to retake the UNT two times during one year.

No. 5. $95 \%$ of respondents answered to the question. $55 \%$ of respondents supported the idea of two exams in the future but $40 \%$ of respondents were against of it.

No. 6. The majority of respondents replied that international tests assesses student's knowledge properly and fairly. Advantage of international test is possibility to retake test couple times during a year. International test has break between exam sections that students can have some rest. Disadvantage of international test is expensive and results come late.

No. 7. For the last question, what would you do if you fail international test, the majority of students replied that they will retake it.

II. Perception of students who did not take the UNT/CTA but will have it after finishing high school/vocational school.

Students who will take the UNT, were mainly $11^{\text {th }}$ grade high school students and 10 of them were vocational school students. None of them had taken international tests. Therefore, the researcher asked students' opinion only about the UNT/CTA.

a) Focus group results: The focus group consisted of four students. Two of them were $11^{\text {th }}$ grade high school students and two were vocational school students. There were two females and two males. Two high school students were against the UNT/CTA. One vocational school student was neutral and was silent during the interview. The second vocational student criticized and encouraged the UNT/CTA simultaneously. All four respondents argued that the UNT/CTA does not evaluate students' knowledge properly.A female secondary school student was angry with school administration. She said that school administration discriminates high school students in accordance with their grades. 11th year high school students during one year get ready for the UNT. Before taking the real UNT, high school students take several practice tests. Students who receive low scores from practice test, must quit high school. The UNT results show high school's ranking. Therefore, school administration makes academically weak students to quit university. As an example, she explained the story of her brother. The school administration forced respondent's brother to quit high school. The respondent's brother objected and wanted to take the UNT. But school administration artificially created a hostile environment and did not let him to study in the UNT preparatory classes. In spite of school resistance, the respondent's brother went to different the UNT preparation courses, then took the UNT, and got high scores.

Respondents continued to complain about school teachers and administration's psychological pressure. Kazakhstan's government ranks high schools in accordance with the UNT results. If students receive high scores from the UNT, it means that school teachers did good work. If students receive low scores, it means that school administration and teachers do not work with students. Therefore, school administration and teachers try to get rid of students who have bad academic performance. If a student with bad academic performance quits school, he/she will not take the UNT, in a result loses the chance to study at university.

Respondents continued that the UNT is very stressful, therefore, suicide is common evidence after the UNT.

They claimed that it is injustice that a student studies for 11 years and has the best grades, after three and a half hours comes out with the result that she/he is not a suitable student for "Altyn Belgi". Participants complained about the UNT question and structure. They believed that the UNT was only memorization and a waste of time. They said that the UNT does not evaluate knowledge properly and it is some kind of a lottery ticket for the University. Any student can guess and get the best grades. In other case a student who studied hard and has real knowledge might confuse circles and receive low scores from the UNT. For the question concerning what they think about the future two part tests, they responded that it will increase corruption in the universities and double stress.

Survey Results: The purpose of the survey was to ask high school students/vocational school students about the UNT/CTA. The survey was distributed to respondents who did not take the UNT. Respondents had not taken 
international tests. Therefore, the survey did not include questions about international tests. The survey was filled out by 10 vocational school students and 30 high school students. In total, 40 students completed the survey. The survey consisted of eight closed questions and seven open questions. Closed questions had three possible answers as Yes, No, and No response. Open questions were about the respondent's personal opinion. Most of students did not complete the open questions.

\begin{tabular}{|c|c|c|c|c|}
\hline$\#$ & Question & Yes & No & $\begin{array}{c}\text { No } \\
\text { Response }\end{array}$ \\
\hline 1. & $\begin{array}{c}\text { Do you agree that UNT/CTA is an } \\
\text { effective entrance test to } \\
\text { university? }\end{array}$ & $68 \%$ & $33 \%$ & $0 \%$ \\
\hline 2. & $\begin{array}{c}\text { Do you agree that UNT evaluates } \\
\text { your knowledge properly? }\end{array}$ & $73 \%$ & $28 \%$ & $0 \%$ \\
\hline 3. & $\begin{array}{c}\text { Do you believe that studying for } \\
\text { the UNT/CTA assists in increasing } \\
\text { your school knowledge? }\end{array}$ & $93 \%$ & $5 \%$ & $3 \%$ \\
\hline 4. & $\begin{array}{c}\text { Do you think that the UNT/CTA is } \\
\text { only memorization of knowledge } \\
\text { might be forgotten after a short } \\
\text { time? }\end{array}$ & $33 \%$ & $68 \%$ & 0 \\
\hline 5. & $\begin{array}{c}\text { Do you believe that the UNT/CTA } \\
\text { will define your destiny? }\end{array}$ & $63 \%$ & $38 \%$ & $0 \%$ \\
\hline 6. & $\begin{array}{c}\text { Do you think that the UNT/CTA is } \\
\text { a stressful test? }\end{array}$ & $78 \%$ & $20 \%$ & $3 \%$ \\
\hline 7. & $\begin{array}{c}\text { Did your health worsen during } \\
\text { preparation for the UNT/CTA? }\end{array}$ & $28 \%$ & $43 \%$ & $30 \%$ \\
\hline 8. & Are you afraid of the UNT/CTA & $44 \%$ & $31 \%$ & $25 \%$ \\
\hline
\end{tabular}

Open questions: 1) what do you think about the UNT/CTA, 2 ) if you receive low score, what will you do, 3) what is the most scaring for you during the UNT, 4) what do you suggest to improve the structure of the UNT/CTA, 5) what do you think about the future UNT which will be divided into two parts such as School Exam and University Entrance Exam, and what you recommend? 6) what will you do if you do not receive expected scores from the UNT? 7) what will be parents' and school administration reaction if you do not receive expected scores from the UNT? Only four respondents replied to open questions. They wrote that the UNT is effective tool to assess the big number of students and it is very important exam. To the last questions, respondents replied that their parents, school teachers and administration will be unhappy and upset if they fail the UNT.

\section{Discussion}

The researcher studied two group's response and showed them in the below diagrams:

1) Do you agree that UNT/CTA is an effective entrance test?

Respondents of first group who took the UNT, $67 \%$ replied that the UNT is not effective, $25 \%$ answered that the UNT is effective, $8 \%$ did not reply. Respondents from group two, who did not take the UNT/CTA but will take after finishing high school, $67 \%$ replied to the question that the
UNT is effective, $33 \%$ said that the UNT is not effective.



Respondents who had the UNT /CTA

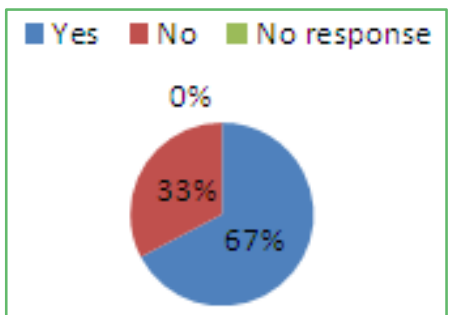

Respondents who will have the UNT/CTA

2) Do you agree that UNT/CTA evaluates your knowledge properly?

Respondents of first group who took the UNT, $75 \%$ answered that the UNT does not evaluate knowledge properly, $10 \%$ said that the UNT evaluates properly, $15 \%$ did not reply.

Respondents from group two, who did not take the UNT/CTA but will take after finishing high school, $72 \%$ replied to the question that the UNT evaluates properly, $28 \%$ said that the UNT does not evaluate knowledge fairly.

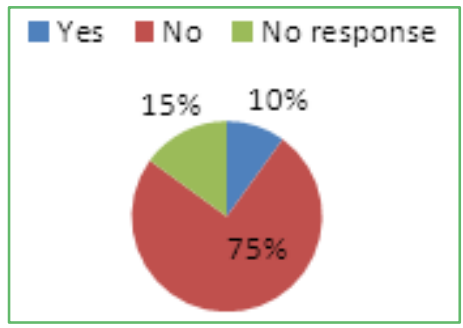

Respondents who had the UNT /CTA

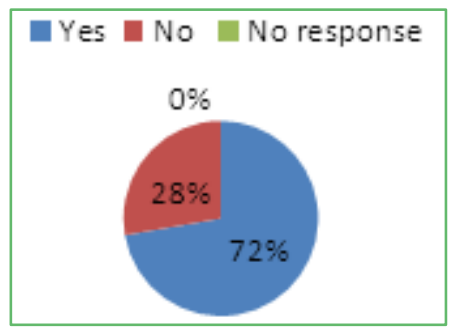

Respondents who will have the UNT/CTA

3) Do you believe that studying for UNT/CTA assists in increasing your school knowledge? Respondents of first group who took the UNT, $52 \%$ believe that the UNT helps to improve knowledge, $45 \%$ disagreed with statement that the UNT increases knowledge, 3\% did not reply. Respondents 
from group two, who did not take the UNT/CTA but will take after finishing high school, 92\% replied that the UNT assists to increase knowledge. $5 \%$ said that the UNT does not help to increase knowledge, $3 \%$ did not write the answer.

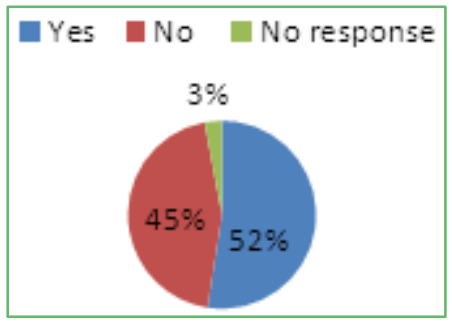

Respondents who had the UNT /CTA

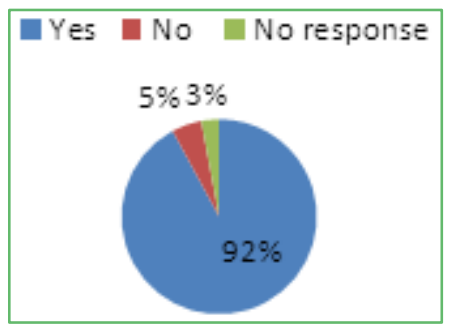

Respondents who will have the UNT/CTA

4) Do you believe that UNT/CTA is only memorization of knowledge that might be forgotten after a short time?

Respondents of first group who took the UNT, 65\% answered that the UNT is memorization of information might be forgotten after a short time, $5 \%$ said that the UNT is not only memorization, and knowledge will not be forgotten, $30 \%$ did not reply. Respondents from group two, who did not take the UNT/CTA but will take after finishing high school, $67 \%$ believe that the UNT is not only memorization, and they will not forget knowledge that they acquired during the UNT preparation. 33\% respondents replied that they will forget knowledge during the UNT preparation after short time.

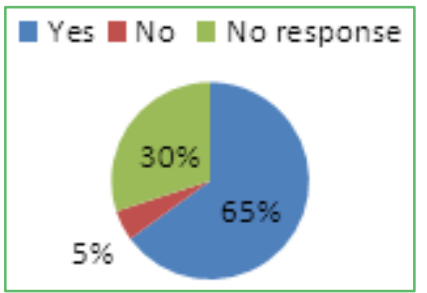

Respondents who had the UNT /CTA

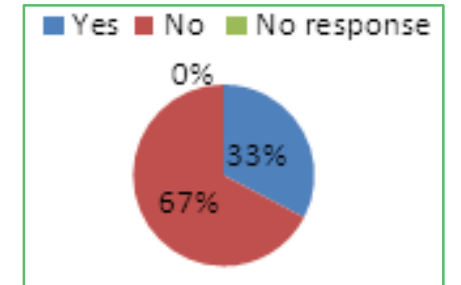

Respondents who will have the UNT/CTA

According to survey, high school students (who did not have the UNT but will have it) have positive opinion about the UNT. But majority of them did not reply open questions. Students who took the UNT/CTA, completed the open questions of the survey, and openly criticized the UNT. According to focus group, both groups said that the $\mathrm{UNT} / \mathrm{CTA}$ is a good method to assess a big amount of students and distribute scholarships. But the UNT/CTA does not evaluate student's knowledge properly. It does not evaluate student's critical thinking, writing or communication skills. The UNT/CTA is like a lottery ticket that student can guess answers. The UNT/CTA has many questions about facts that make students to memorize answers.

\section{Survey Results of Joined Two Groups}

The researcher combined two group respondents' answers and showed study results in percents.

To the question 1) "Do you agree that the UNT/CTA is an effective entrance test to university? ", $46 \%$ of respondents believe that the UNT is effective and the most suitable test for Kazakhstani universities' admission. $50 \%$ of respondents found the UNT/CTA is not effective test. $4 \%$ of respondents did not have any opinion about the UNT/CTA (table 1).

To the question 2) "Do you agree that the UNT/CTA evaluates your knowledge properly?", $41 \%$ of respondents agreed with the statement, but $51 \%$ of respondents said that the UNT/CTA does not evaluate knowledge properly, $8 \%$ of respondents did not have any opinion

To the question 3) "Do you believe that studying for the UNT/CTA assists in increasing your school knowledge?", $73 \%$ of respondents replied that the UNT/CTA helps to improve school knowledge, but $25 \%$ disagreed with the statement, the rest of $2 \%$ respondents did not reply the question.

To the question "Do you believe that the UNT/CTA is only memorization and knowledge that might be forgotten after a short time" $49 \%$ replied "yes" and $36 \%$ of respondents disagreed with the question, and $15 \%$ did not reply.

Respondents answers' is given in the below mentioned diagrams. 


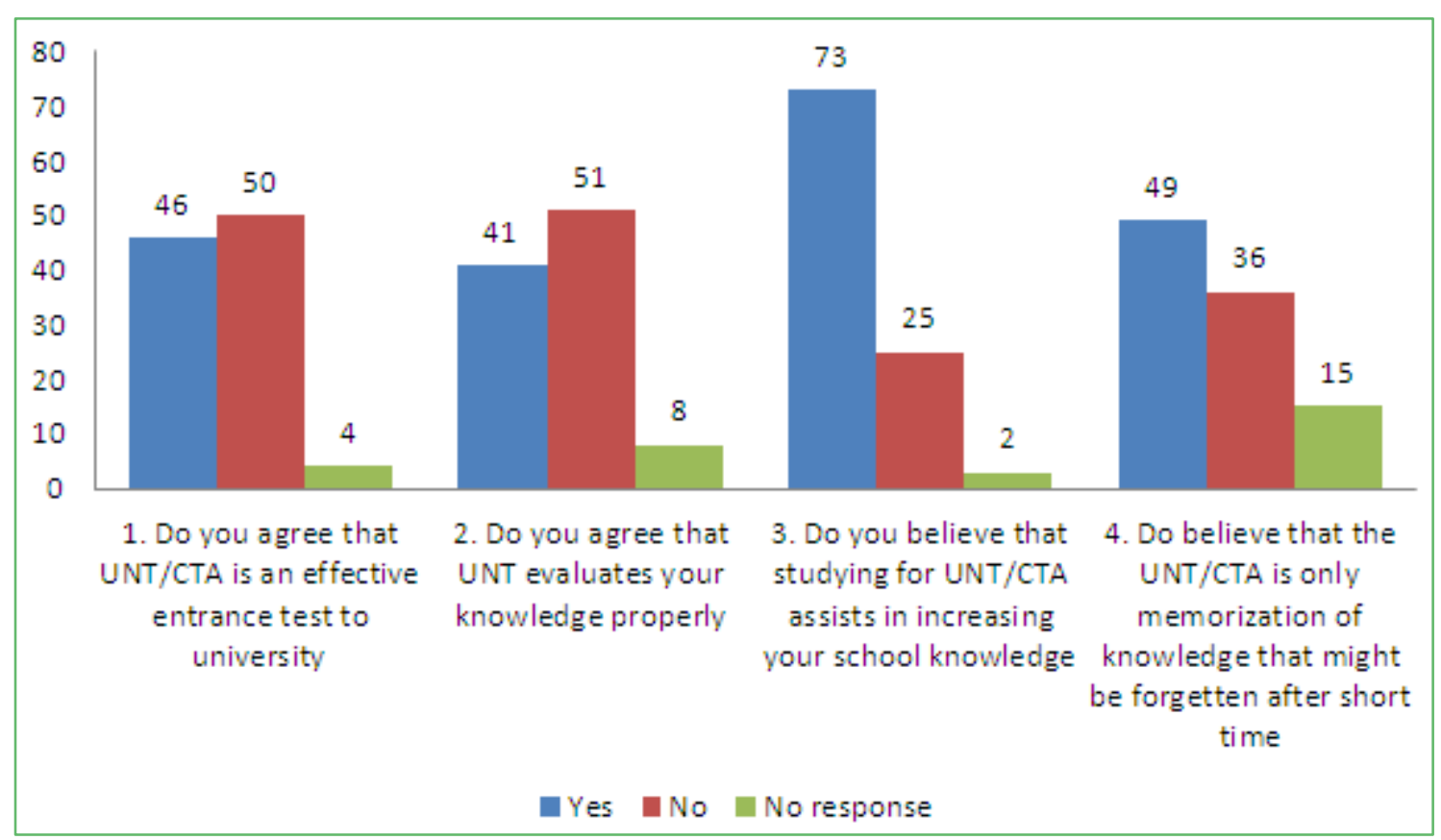

\section{Stress during the UNT/CTA}

To the question "do you think the UNT is a stressful test", response of two groups was: $71 \%$ respondents said that the UNT is a stressful test, $21 \%$ respondents replied that the UNT is not stressful, $8 \%$ respondents did not reply the question.

To the question "do you believe that the UNT/CTA defines your destiny", $63 \%$ respondents replied their future depends on the UNT/CTA results.

Group two, who will take the UNT: $48 \%$ of high school students are afraid of the UNT. $28 \%$ of respondents faced health problems during preparation for the future UNT. High school students claimed that if they receive low scores from the UNT, school administration and teachers will be sad and angry, therefore, they have to work hard.

Group one, students who took the UNT/CTA: $65 \%$ of students were nervous during the UNT. $20 \%$ of students said that their health worsened during the UNT preparation. $40 \%$ of students did not sleep well before the UNT night. $63 \%$ of students had worries and fears before the UNT. $28 \%$ of students had a feeling that they might forget everything and could not write answers. During the UNT, $65 \%$ of students were worried and $45 \%$ had an increased heart rate, $25 \%$ had hand or legs shake. After finishing the UNT, $13 \%$ of respondents had health problems. $8 \%$ said that if they did not receive enough scores, they might commit suicide.

According to research results, it is visible the UNT/CTA is stressful test that students (more than half respondents) could not sleep before exam and had feeling of fears and worries. During and after the UNT/CTA faced health problems. $63 \%$ of respondents perceive the UNT/CTA as an exam that defines their future and destiny.

According to focus groups, participants said that the UNT/CTA is stressful test especially for students who want to prove "Altyn Belgi" status. High school students for 11 years studied with excellent grades, were the best outstanding students, but did not receive high scores from the UNT because of questions about detailed facts. School administration and teachers make students believe that the UNT is an exam that defines destiny. In addition, school administration makes academically weak high school students to quit school, do not let them to take the UNT. If a high school student fails the UNT, it is a minus for school. The reason is high school students are ranked in accordance with the UNT results.

\section{International test}

Among respondents, 32 students took IELTS, 6 took AP, 3 took TOEFL and 9 took SAT tests. Some of them took IELTS, TOEFL, AP and SAT simultaneously. They are university students. Twenty two (80\%) students suggested having the UNT questions and structure similar to international tests questions. Four students said that the UNT cannot be like an international test because Kazakhstan has different system of education and teaching methodology.

Below mentioned table gives more information about stress level between international test and UNT.

\begin{tabular}{|c|c|}
\hline UNT & International test (IT) \\
\hline $65 \%$ claimed that UNT is stressful & $35 \%$ claimed that IT is stressful \\
\hline $\begin{array}{c}65 \% \text { were worried during the } \\
\text { UNT }\end{array}$ & vorried during IT \\
\hline $\begin{array}{l}10 \% \text { think that UNT/CTA evaluates } \\
\text { knowledge properly }\end{array}$ & $\begin{array}{l}78 \% \text { think that UNT/CTA } \\
\text { evaluates knowledge properly }\end{array}$ \\
\hline
\end{tabular}

\section{Future 2 part exams/tests}

The majority of research participants were against of the future two part exams. They believed that two part exams will increase corruption and double stress. They were doubtful about future test quality. They preferred to keep the present UNT /CTA format and wished to improve the section 
of History questions.

\section{Conclusions}

UNT has advantages and disadvantages. $46 \%$ of respondents said that the UNT is an effective entrance test to university. But $50 \%$ of participants disagreed with the effectiveness of the UNT. 4\% did not reply for the question.

$51 \%$ of participants said that the UNT does not assess knowledge properly. Only $41 \%$ of participants agreed that UNT assesses knowledge properly. 8\% did not reply for the question.

International Tests: Interesting fact that students who had international tests such as TOEFL, SAT, AP, IELTS had more critical opinion about the UNT rather than students who did not have experience with international tests. $11^{\text {th }}$ grade high school students had positive opinion about the UNT. International test has less stress than UNT. The UNT has more responsibilities rather than international test. The UNT is an exam to finish high school, be admitted to university and get scholarship and, it is given only once a year. International test is like an optional exam which you can retake several times. The majority of university students wished to see the UNT as an international test. It is difficult to make the UNT as an international test such as TOEFL, AP, SAT, IELTS. The reason is Kazakhstan has different culture, environment, system of education and teaching methodology. But, the UNT can acquire some question structures from international tests. Currently UNT has only closed questions, with 4 answers. Therefore, implementing new different type of questions to the UNT will be an advantage. The UNT with various type of questions and written assignments will allow to assess students' knowledge, creativity and critical thinking.

UNT and Stress: According to the research results, all students answered optimistically to the question: "what will you do if you fail the UNT". Thus, the UNT cannot be a reason for suicide. An applicant/student who wants to commit suicide because of low scores, usually he/she has psychological problems for a long time. A psychologically weak person can commit suicide for any reason that can hurt $\mathrm{him} /$ her. It can be a quarrel, disagreement with friends, with relatives or any other unpleasant situation. When these high school students receive low scores from UNT, it can be an impulse to commit suicide. To prevent suicide, not only psychologists but also parents and school administration must be very attentive to school students. Since the UNT does not evaluate students' knowledge properly, UNT results should not be a tool to assess school's ranking. Daily gathered insults, threatens, psychological pressure from parents, teachers, administration might negatively effect on students health and nervous system, as a result a student might commit suicide. Thus, not only the UNT questions but also the concept of the UNT should be changed. Parents, teachers and school administration must support and encourage high school students and make them understand that failure of the UNT or low scores is not the end of world.

Future UNT: high school exam and university entrance exams: The majority of participants were against of the future two part tests/exams. They believed that the future exams/tests will increase corruption, stress and chaos. Participants are doubtful about the future tests/exams quality. They wish to have the same UNT format but to change questions. Majority of students requested to eliminate History section or do not ask illogic questions.

For further studies, the researcher recommends to study Kazakhstani secondary school ranking system, comparison of the UNT and international test (AP or SAT) and psychological support at Kazakhstani secondary schools.

\section{REFERENCES}

[1] Capital [Internet]. [Place unknown]; The number of universities will be decreased, количество вузов сократится; 2013 [updated 2013 Mar 13; cited 2014 Apr 10 ]. Available from:http://kapital.kz/details/12703/chislo-vuzov-sokratitsya .html

[2] KazPortal.kz [Internet]. [Place unknown]: Education in the Republic of Kazakhstan, Образование в Республике Казахстан; 2015 [cited 2015 Sep 20]. Available from: http://www.kazportal.kz/obrazovanie-v-respublike-kazahstan /

[3] National Center of Testing [Internet]. Astana: The competition for the award of educational grants, kонкурс по присуждению образовательных грантов; 2015 [cited 2015 Sep 20]. Available from:

http://www.testcenter.kz/en/entrants/grant/?sphrase_id=9708 6

[4] Nazarbayev University [Internet]. Astana: How to apply:2015 [cited 2015 Sep 20]. Available from:

http://admissions.nu.edu.kz/wps/portal/!ut/p/b0/fcsxDoAgD EDR0zBX4-bm4BIUFtIoKSRQGqwab6_xAG7_DR8szGA Zz0iosTCm18u1515Qg2m7YWRKcQ-mOXjzlSpuB6o3TSi XFhRJ99dOi_sEE1iw-e3IBIsg-Z8XJOfhAdxuZKQ!/

[5] KBTU [Internet]. Almaty: ISE:2014 [cited 2014 Apr 10]. Available from: http://ise.kz/?page_id=17

[6] Raushan Karimova [Internet] [Place unknown]:UNT has become a kind of indicator of mental health of high school students, Раушан Каримова: ЕНТ стало своеобразным индикатором психологического здоровья выпускников). 2013 [updated 2013 May 27; cited 2014 Apr 10]. Available from: http://kazmedia.kz/?p=6359

[7] National Testing Center. [Internet]. Astana: Unified National Testing (UNT): 2015 [cited 2015 Sep 20 ]. Available from: http://www.testcenter.kz/en/entrants/ent/

[8] REGTV [Internet]. [Place unknown]: Holders of "Altyn Belgi" without scholarship, will study for free, Оставшиеся без грантов обладатели "Алтын Белги" будут учиться бесплатно: 2015 [updated 2015 Aug 19; cited 2015 Sept 20]. Available from:

http://www.regtv.kz/chinovniki/item/4560-ostavshiesya-bezgrantov-obladateli-altyn-belgi-budut-uchitsya-besplatno.html 
[9] National Testing Center [Internet]. Astana: Unified National Testing (UNT): 2015 [cited 2015 Sep 20 ]. Available from: http://www.testcenter.kz/en/entrants/ent/

[10] National Testing Center [Internet]. Astana: Complex Testing of applicants:2015 [cited 2015 Sep 20 ]. Available from: http://www.testcenter.kz/en/entrants/kta/

[11] National Testing Center [Internet]. Astana: Unified National Testing (UNT): 2015 [cited 2015 Sep 20 ]. Available from: http://www.testcenter.kz/ru/entrants/ent/

[12] News of Kazakhstan [Internet]. [Place unknown ]: Additional scores were added to "Altyn Belgi" candidates after their complaints about incorrect questions of the UNT , Претенденткам на "Алтын белгі" из Кызылорды добавили балл после жалобы на некорректные вопросы: 2015 [updated 2013 Jun 17; cited 2015 Sep 20 ]. Available from: http://tengrinews.kz/kazakhstan_news/pretendentkam-altyinbelg-kyizyilordyi-dobavili-ball-jalobyi-236342/

[13] KTK news [Internet]. [Place unknown ]: 30 students failed UNT due to technical problems, сразу 30 выпускников провалили ЕНТ из-за технических проблем: 2013 [cited 2014 Apr 10]. Available from:http://www.youtube.com/watch?v=_M-pdv7WmVM.

[14] 365info.kz [Internet]. Almaty: Afterword to the tragedy of national scale - UNT, Послесловие к трагедии национального масштаба - ЕНТ: 2015 [updated $2015 \mathrm{Jul} 16$; cited 2015 Sep 20]. Available from: http://365info.kz/2015/06/posleslovie-k-tragedii-nacionalnog o-masshtaba-ent/

[15] Kozina, B. [Internet]. [Place unknown ]: Health Specialist, Exams... how to overcome UNT , Экзамены... Как пережить ЕHT?: 2011 [updated 2011 May 23; cited 2014 Apr 10 ]. Available from:

http://www.zoj.kz/populiarnie/psyhologiya/992-ekzamenyka k-perezhit-ent.html

[16] 365 info.kz [Internet]. Almaty: Afterword to the tragedy of national scale - UNT, Послесловие к трагедии национального масштаба - ЕНТ: 2015 [updated 2015 Jul 16; cited 2015 Sep 20]. Available from: http://365info.kz/2015/06/posleslovie-k-tragedii-nacionalnog o-masshtaba-ent/

[17] United National Testing[Internet]. Almaty: Attitude of Society to the United National Testing, Отношение общественности к единому национальному тестированию:2012 [cited 2014 Sep 20] Available from: http://www.slideshare.net/Ipolito/ss-12950409

[18] News Kazakhstan [Internet]. Astana: In Kazakhstan UNT will be changed into two part tests from 2015, ЕНТ будет заменено на два вида тестов с 2015 года в Казахстане:2013 [updated 2013 Sep 19; cited 2014 Apr 10 ]. Available from:

http://newskaz.ru/society/20130919/5564113.html

[19] METAKZ [Internet]. [Place unknown ]: Kazakhstani students will have the UNT couple times during a year , Казахстанским выпускникам разрешат пересдавать ЕНТ несколько раз за год: 2013 [updated 2013 Oct 29; cited 2014 Apr 10]. Available

from:http://meta.kz/novosti/kazakhstan/839122-kazahstanski m-vypusknikam-razreshat-peresdavat-ent-neskolko-raz-za-g od.html 